\title{
A NEW COMBINATION IN BRYUM (MUSCI: BRYACEAE)
}

\section{Harold Robinson}

Department of Botany, National Museum of Natural History, MRC 166, P.O. Box 37012

Smithsonian Institution, Washington, D.C. 20013-7012

\section{ABSTRACT}

A new combination in Bryum is provided for the Andean Anomobryum worthleyi.

KEY WORDS: Anomobryum, Bryum, new combination.

Recent papers by John R. Spence (Spence and Ramsay 2002; Spence 2005a, b) mention problems concerning the typification of the genus Bryum Hedw., and the resulting effects on the status of the genus Anomobryum Schimp. The papers accept the fact that Anomobryum is congeneric with the common Bryum argenteum Hedw. Unfortunately for the the generic status of Anomobryum, Bryum argenteum had been chosen by E.G. Britton as lectotype of the genus Bryum (Britton 1918). Such lectotypifications made by staff of the New York Botanical Garden during the early $20^{\text {th }}$ Century were often arbitrary and sometimes so buried in the literature as to be easily overlooked. As such they were often later rejected even without resort to any committee. However, the selections were not always unreasonable, and such lectotypifications were not always rejected. The Britton lectotypification had been widely accepted, and was cited in Index Muscorum (Van der Wijk, Margadant and Florschütz 1959). It is only recently that the full possible consequences of the Britton lectotypification have become apparent, for Anomobryum and for other elements traditionally placed in Bryum. Spence and Ramsay (1999) proposed conservation of the name Bryum with another type, but as indicated by Spence (2005), this has been rejected.

The consequences of the typification of Bryum by B. argenteum are most noticeable in many other parts of what has been called Bryum, 


\section{Phytologia (June 2006) 88(1)}

with the resurrection of such genera as Ptychostomum Hornsch., the description of new genera such as Gemmabryum J.R. Spence and H.P. Ramsay, Ochiobryum J.R. Spence and H.P. Ramsay, Plagiobryoides J.R. Spence, and the elevation of Leptostomopsis (Mull.Hal.) J.R. Spence \& H.P. Ramsay (see Spence 2005a, b). These are added to the earlier new genus Rosulobryum J.R. Spence (1996).

The consequences of the synonymy of Anomobryum with Bryum are not as great, since the number of species of Anomobryum is limited, and many of those species have preexisting combinations in a broader concept of Bryum (Allen 2002; Ochi 1980). One South American species where a combination is required is treated below.

Bryum worthleyi (H. Rob.) H. Rob., comb. nov. basionym:

Anomobryum worthleyi H. Rob., Bryologist 70: 320 (1967). Bolivia, Peru.

This is the same species treated by Ochi (1980) as Bryum alboimbricatum Ochi, nom. nov. for Bryum albidum Broth. in Herz.., Biblioth. Bot. 87: 81 (1916), hom. Illeg., non P. Beauv. 1805; nec Copp. 1911. When Ochi (1980) provided the nom. nov. he was evidently unaware of the already existing name Anomobryum worthleyi (Robinson 1967) which had priority.

The name of the species honors the late Elmer Worthley, who collected the type near Machu Picchu, Peru in 1962.

\section{LITERATURE CITED}

Allen, B. 2002. Moss Flora of Central America. Part 2.

Encalyptaceae-Orthotrichaceae. Monog. Syst. Bot. Missouri Bot. Garden 90: 1-699.

Britton, E.G. 1918. p 490. In: N.L. Britton, Flora of Bermuda, Charles Scribner's Sons, NewYork. 585 pp.

Ochi. H. 1980. A revision of the Neotropical Bryoideae, Musci (First Part). J. Fac. Educ. Tottori Univ., Nat. Sci. 29(2): 49-154. 
Robinson, H. 1967. Six new bryophytes from South America. Bryologist 70: 317-322.

Spence, J.R. 1996. Rosulobryum genus novum (Bryaceae). Bryologist 99: 221-225.

. 2005a. New genera and combinations in Bryaceae (Bryales, Musci) for North America. Phytologia 87((1): 15-28.

. 2005b. New genera and combinations in the Bryaceae (Bryales, Musci) for Australia. Phytologia 87(2): 61-72.

and H. P. Ramsay. 1999. (1435) Proposal to conserve the name Bryum (Musci, Bryaceae) with a conserved type. Taxon 48: 827-828.

and . 2002. The genus Anomobryum Schimp. (Bryopsida, Bryaceae) in Australia. Telopea 9(4): 777-792.

Van der Wijk, R., W.D. Margadant and P.A. Florschütz. 1959. Index Muscorum, I, A-C. Regnum Veg. 17: i-xxviii, 1-548. 


\section{$2 \mathrm{BHL}$ Biodiversity Heritage Library}

Robinson, Harold Ernest. 2006. "A new combination in Bryum (Musci:

Bryaceae)." Phytologia 88, 111-113. https://doi.org/10.5962/bhl.part.17850.

View This Item Online: $\underline{\text { https://www.biodiversitylibrary.org/item/46936 }}$

DOI: https://doi.org/10.5962/bhl.part.17850

Permalink: https://www.biodiversitylibrary.org/partpdf/17850

\section{Holding Institution}

New York Botanical Garden, LuEsther T. Mertz Library

\section{Sponsored by}

The LuEsther T Mertz Library, the New York Botanical Garden

\section{Copyright \& Reuse}

Copyright Status: In copyright. Digitized with the permission of the rights holder.

Rights Holder: Phytologia

License: http://creativecommons.org/licenses/by-nc-sa/3.0/

Rights: https://biodiversitylibrary.org/permissions

This document was created from content at the Biodiversity Heritage Library, the world's largest open access digital library for biodiversity literature and archives. Visit BHL at https://www.biodiversitylibrary.org. 